一技術報告一

\author{
酵素抗体法による無髄毛髪の ABO 式血液型検査 \\ 阿久津智子 $* 1$, 池谷 博*2, 渡邊 賢 $* 1$, 櫻田宏一 $* 1$ \\ 科学警察研究所*1, 京都府立医科大学医学部法医学教室*2 \\ 干277-0882 千葉県柏市柏の葉6-3-1*1 \\ 干602-0841 京都府京都市上京区河原町通広小路上儿梶井町 $465 * 2$
}

\title{
ABO Blood Grouping of Non-medullated Scalp Hair Using Immunohistochemical Staining
}

\author{
Tomoko Akutsu*1, Hiroshi Ikegaya*2, Ken Watanabe*1, and Koichi Sakurada*1 \\ National Research Institute of Police Science ${ }^{* 1}$ \\ 6-3-1 Kashiwanoha, Kashiwa, Chiba 277-0882, Japan \\ Department of Legal Medicine, Kyoto Prefectural University of Medicine*2 \\ 465 Kajii-cho Kawaramachi-Hirokoji, Kamigyo-ku, Kyoto, Kyoto 602-0841, Japan
}

(Received 11 May 2009; accepted 1 July 2009)

In this study, to apply immunohistochemical staining to the ABO blood grouping of non-medullated hair samples, the blocking condition and chromogenic substrate of the current protocol were modified. When 3,3',5,5'-tetramethylbenzidine was used as a substrate, the cortex of the longitudinally sectioned non-medullated scalp hair was positively stained parallel to the hair fiber; however, non-specific staining were shown in the medullae of medullated scalp hair. Non-specific staining was improved when blocking was performed using $10 \%$ normal rabbit serum at $37^{\circ} \mathrm{C}$ for $1 \mathrm{~h}$. In the blind trial, the ABO blood group of all medullated and non-medullated scalp hair was successfully determined by immunohistochemical staining modified in this study. The biotin-conjugated ulex europaeus I suitable for this method was also validated. In conclusion, it is thought that ABO blood grouping of hair samples using this modified protocol of immunohistochemical staining is useful for screening hair samples before DNA analysis.

Key words: Forensic science, ABO blood grouping, Non-medullated hair, Immunohistochemical staining

緒 言

毛髪は，毛根鞘が付着している場合，DNA 型鑑 定の有用な資料となりうるが，採取された多数の毛
髪資料について，より効率的かつ効果的に DNA 型 鑑定を実施するためには，前段階での資料の選別が 重要となる.

一般的な毛髪の異同識別検査では，まず，現場資 
料と対照資料について形態学的検査が行われ, 対照 資料との間に形態学的類似性が認められる現場資料 について, ABO 式血液型検査が実施される。つづ いて, 対照資料と $\mathrm{ABO}$ 式血液型が一致した現場資 料について, STR 型検査あるいはミトコンドリア DNA 型検査による DNA 型鑑定が実施される.

毛髪を試料とした $\mathrm{ABO}$ 式血液型検査は, 解離試 験法1-3) あるいは酵素抗体法4-9) で実施されている。 解離試験法は, 以前より広く行われている方法であ るが, 試料を数 $\mathrm{cm}$ 消費することから ${ }^{2,3)}$, 短い毛髪 には適用できない, 一方, 酵素抗体法は, 毛髪の縦 断切片などを作製し, 露出させた毛髄質を免疫組織 化学的に染色する方法であり, peroxidase-antiperoxidase 法4-6) あるいは Avidin-Biotin-Peroxidase Complex 法をたは Labeled Streptavidin Biotin 法 $(\text { LSAB 法 })^{7-9}$ による検出法が報告されている。 た，圧挫した毛髪を試料としたビオチン標識タイラ マイドあるいはアルカリホスファターゼ標識抗体に よる検出法も報告されている10,11)。このうち, 警察 に打ける鑑定実務に用いられているのは主に, 縦断 切片を試料とした LSAB 法による酵素抗体法であ り, 試料の消費量が数 $\mathrm{mm}$ と少ないことから, 短 い資料にも適用可能であるが, 毛髄質の発色を観察 し，判定を行うため，無髄毛髪には適用できていな いのが現状である.

毛幹部の毛皮質にも血液型物質が存在することは 免疫電顕法で確認されており ${ }^{12)}$, また, 解離試験法 では毛髄質の有無を問わず ABO 式血液型が判定可 能であることから, 毛皮質にも血液型検査に十分量 の血液型物質が存在すると考えられる. 松井ら ${ }^{11)}$ は 近年, 一晚脱メラニン処理し, 高圧で均一に圧挫し た毛髪試料を用いた酵素抗体法により, 無髄毛髪か らも型判定が可能であることを示唆している．そこ で本研究では, 鑑定実務への応用を前提に, 毛髄質 の有無を問わず適用可能な, 酵素抗体法による $\mathrm{ABO}$ 式血液型検査法を確立することを目的とし, 発色基質やブロッキング条件について改良を行っ た。

なお，鑑定実務においてLSAB法による毛髪か らの $\mathrm{H}$ 型物質の検出に用いられてきた Biomeda 社 製の Biotin conjugated Ulex Europaeus agglutinin I
（ビオチン標識抗 H レクチン）が入手不可能となっ たことから，代替可能な試薬について，併せて検討 を行った。

\section{材料および方法}

\section{1 毛髮試料}

試料は，同意を得て提供を受けた有髄毛髪（A 型 9 名, $\mathrm{B}$ 型 4 名, $\mathrm{O}$ 型 5 名抢よび $\mathrm{AB}$ 型 5 名分) および無髄毛髪 ( $\mathrm{A}$ 型 7 名, $\mathrm{B}$ 型 6 名, $\mathrm{O}$ 型 7 名お よび $\mathrm{AB}$ 型 5 名分）である. なお，有髄毛髪および 無髄毛髪は同一人物に由来するものも含まれる.

\section{2 試薬}

ビオチン標識抗 H レクチンは, Vector Laboratories (Burlingame, CA, USA) 製（VECTOR）, Sigma (St. Louis, CA, USA) 製 (SIGMA), 和光純薬工 業（大阪）製（WAKO），および EY Laboratories (San Mateo, CA, USA)製(EY)の 4 種を購入し, 使用した。また, Biomeda (Foster City, CA, USA) 製（BIO）を陽性対照として使用した。抗 A 抒よ び抗 $\mathrm{B}$ 抗体は, バイオクローン抗 $\mathrm{A}$ 打よび抗 $\mathrm{B}$ モ ノクローナル抗体 (オーソ), モノクローナル抗 A および抗 B ワコー (ワコー), イムコア抗 A および 抗 $\mathrm{B}$ モノクロ (イムコア), 抗 A 抢よび抗 B 抗体 ネオコクサイ（コクサイ）を，それぞれオーソクリ ニカルダイアグノスティックス (東京), 和光純薬 工業，カイノス (東京) およびシスメックス (兵庫) より購入し, 検討した. ブロックエースは, 大日本 製薬（大阪）より購入した. 10\%ウサギ正常血清, ビオチン標識抗マウス $\operatorname{IgG}+\operatorname{Ig} \mathrm{A}+\mathrm{IgM}$ ，ペルオキ シダーゼ標識ストレプトアビジン, アルカリホスフ アターゼ標識ストレプトアビジンおよび 3-amino9-ethyl-carbazol (AEC) 溶液は, いずれもニチレイ バイオサイエンス（東京）より購入した。また， 3,3',5,5'-tetramethylbenzidine (TMB) stabilized substrate for HRP は Promega (Madison, WI, USA) より購入した。 5-Bromo-4-chloro-3-indolylphosphate p-toluidine (BCIP) および 2-amino-2methyl-1,3-propandiol (AMP) は和光純薬工業よ り購入した. BCIP/nitroblue tetrazolium chloride (NBT) liquid substrate system は Sigma より購入し た. その他の試薬は, 和光純薬工業製の試薬特級品 
を使用した。

\section{3 試料の前処理}

試料は，洗剤抢よび水による洗浄，ジエチルエー テルによる脱脂を行った後, 内村ら ${ }^{7)}$ の方法に従 い, 室温で20分間脱メラニン処理を行った. 脱メラ ニン処理を行った試料を約 $1 \mathrm{~mm}$ 長に切断し, 反応 板に貼付したものについて，実体顕微鏡下でメスを 用いて, 最大径付近で二分されるように縦断切片を 作製し，毛髄質および毛皮質を露出させた。なお， 反応板は，スライドグラス上にセロハン両面テープ （セルタック，二チバン，東京）およびファイル穴 補強フィルム（プラパッチ，エーワン，東京）を貼 付して作製した.

\section{4 ビオチン標識抗 $\mathbf{H}$ レクチンの検討}

反応性の検討は, $\mathrm{A}, \mathrm{B}, \mathrm{O}$ および $\mathrm{AB}$ 型の有䯣毛 髪を試料とし，100, 50, 25, 12.5 および $6.25 \mu \mathrm{g} / \mathrm{ml}$ に 希釈した VECTOR, SIGMA, WAKO およびEYの ビオチン標識抗 Hレクチンを用いて行った。酵素 抗体法は, 内村ら ${ }^{8)}$ の方法に準じて行った。試料を 10\%ウサギ正常血清により室温で10分間ブロッキン グした後，リン酸緩衝生理食塩水 $(\mathrm{PBS}(-))$ で希

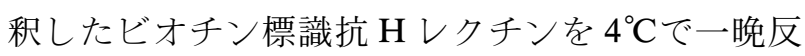
応させた. PBS $(-)$ で 3 回洗浄した後, ペルオキシ ダーゼ標識ストレプトアビジンを滴下し，室温で20 分間反応させた. PBS $(-)$ で 3 回洗浄した後, 水分 をよく除き，AEC 溶液を滴下し，室温で10分間発 色させた. 発色は, 反応板を蒸留水で洗浄すること で停止させた. 判定は, 実体顕微鏡にて落射光下で 毛髄質の赤色の発色を観察することにより行った。

非特異的反応の有無を確認するため, 縦断切片に $0.05 \mathrm{M}$ 過ヨウ素酸溶液を滴下して室温で 90 分間反 応させ, 血液型物質を変性させた陰性対照毛髪に, $100 \mu \mathrm{g} / \mathrm{ml}$ のビオチン標識抗 Hレクチンを滴下 し, 同様の操作を行った.

至適希釈濃度の検討は, $\mathrm{A}, \mathrm{O}$ および $\mathrm{AB}$ 型各 4 名分, $\mathrm{B}$ 型 5 名分の計 17 名分の有髄毛髪を試料と し, PBS (-)で100あるいは $50 \mu \mathrm{g} / \mathrm{ml}$ に希釈した VECTOR のビオチン標識抗 H レクチンについて行 った. 両濃度に対して, 過ヨウ素酸処理した陰性対 照毛髪を用いて非特異的反応の有無を確認した。

\section{5 毛髪の酵素抗体法による ABO 式血液型検査の 改良}

\section{5-1 発色基質の検討}

酵素抗体法は, 内村 $5^{8)}$ の方法を一部改変して行 った. 試料を10\%ウサギ正常血清により室温で10分 間ブロッキングした後, 抗 A 抗体および抗 B 抗体 （オーソ，80倍希釈）を $4{ }^{\circ} \mathrm{C}$ で一晚反応させた. ビ オチン標識抗マウス $\operatorname{IgG}+\operatorname{Ig} \mathrm{A}+\operatorname{IgM}$ を室温で 10 分, ペルオキシダーゼ標識またはアルカリホスファ ターゼ標識ストレプトアビジンを室温で 5 分間反応 させ, 発色基質を滴下して発色させた後, 蒸留水で 洗浄して発色を停止させた. 各行程の間でそれぞれ 3 回の洗浄を行った。抗体の希釈および洗浄には, ペルオキシダーゼの系では PBS $(-)$ を，アルカリ ホスファターゼの系ではトリス緩衝生理食塩水を使 用した。 BCIP は， $50 \mathrm{mM}$ の AMP に溶解して使用 した. 発色時間は, AEC は室温10分, TMB は室温 5 分, $\mathrm{BCIP}$ および $\mathrm{BCIP} / \mathrm{NBT}$ は $37^{\circ} \mathrm{C} 1$ 時間とし た。AEC抢よび TMBについては，A，B，O拈よ び $\mathrm{AB}$ 型の有髄掞よび無髄毛髪を試料とし, BCIP および BCIP/NBTについては無髄毛髪を試料とし た.いずれの発色基質に対しても, 過ヨウ素酸処理 した陰性対照毛髪を用いて非特異的反応の有無を確 認した.

\section{5-2 抗体の検討}

TMB による毛髄質の非特異的発色を改善するた め, 一次抗体の検討を行った. $\mathrm{A}, \mathrm{B}, \mathrm{O}$ および $\mathrm{AB}$ 型の有髄および無髄毛髪を試料とし, オーソ（現行 法), ワコー, イムコア抢よびコクサイの 4 種の抗 A 抗体抢よび抗 B 抗体について, PBS $(-)$ で80倍 希釈したものを用いて検討を行った．その他の操作 は，発色基質の検討と同様に行った.

\section{5-3 ブロッキング条件の検討}

TMB による毛髄質の非特異的発色を改善するた め, ブロッキング条件の検討を行った， A, B， O お よび $\mathrm{AB}$ 型の有髄抢よび無髄毛髪を試料とし，10\% ウサギ正常血清 (現行法), ブロックエース（5\%お よび $2 \%)$ ，スキムミルク $(5 \%$ および $2 \%)$, あるい は bovine serum albumin（BSA, 5\%) を滴下し, 室 温で10分間ブロッキングを行った。 また，10\%ウサ ギ正常血清は， $37^{\circ} \mathrm{C} て ゙ 1$ 時間のブロッキングについ 
ても検討した．その他の操作は発色基質の検討と同 様に行った.

\section{5-4 検査法の検証}

まず，毛皮質の発色部位について詳細に観察する ために，AB 型の有髄および無髄毛髪について，10 $\%$ \%サギ正常血清で $37^{\circ} \mathrm{C} 1$ 時間のブロッキングを 行い, 抗 A 抗体抢よび抗 B 抗体としてオーソ $(80$ 倍希釈), ビオチン標識抗 Hレクチンとして VECTOR $(50 \mu \mathrm{g} / \mathrm{ml})$ を用い, TMB にて発色させた後 反応板からはがし，別のスライドグラスにエンテラ ンニュー（Merck, Darmstadt, Germany）を用いて 封入し, 透過型の光学顕微鏡で観察した。つづい て, 有髄毛髪 ( $\mathrm{A}$ 型 4 名, B 型 5 名, $\mathrm{O}$ 型 5 名打よ び $\mathrm{AB}$ 型 4 名分）打よび無髄毛髪（A 型 4 名, $\mathrm{B}$ 型 4 名, $\mathrm{O}$ 型 4 名抢よび $\mathrm{AB}$ 型 3 名分）を用いて, 同 検査法でいずれの毛髪試料においても $\mathrm{ABO}$ 式血液 型が正しく判定できるかを検証した。なお，判定は 鑑定実務を想定し，実体顕微鏡にて落射光下で行っ た.

\section{5-5ブラインドテスト}

確立した検査法について, 検査者に血液型が分か らないようにランダムに番号を付した, 毛髪 48 試料 (有髄毛髪23試料および無髄毛髪 25 試料)を用いて, ブラインドテストを実施した。なお，判定は鑑定実 務を想定し, 実体顕微鏡にて落射光下で行った.

\section{結 果}

\section{1 ビオチン標識抗 $\mathbf{H}$ レクチンの検討}

VECTOR, SIGMA, WAKO およびEY のビオチ

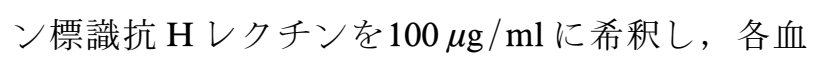
液型の有髄毛髪に対する反応性を実体顕微鏡にて落 射光下で観察した結果を Fig. 1 に示す. VECTOR においては，毛髄質に赤色の特異的な発色が認めら れたが，一部の陰性対照毛髪の毛髄質が非特異的に 弱く発色していた. また, 特異的な発色の強さは試 料によって異なっていた。一方, SIGMA および WAKOは，すべての試料において陰性対照毛髪の 毛皮質および毛髄質に強い非特異的発色が認められ た、また，EYについては，いずれの試料に対して も発色が認められなかった。 なお，いずれの試料に おいても, 陽性対照である BIO で毛髄質に特異的
Table 1 Results of immunohistochemical staining of scalp hair using different concentrations of biotin-conjugated ulex europaeus agglutinin 1 .

\begin{tabular}{|c|c|c|c|c|c|}
\hline \multirow{3}{*}{$\begin{array}{l}\text { Blood } \\
\text { group }\end{array}$} & \multirow{3}{*}{$\begin{array}{l}\text { Number } \\
\text { of hair } \\
\text { donors }\end{array}$} & \multicolumn{4}{|c|}{ Number of stained samples } \\
\hline & & \multicolumn{2}{|c|}{$100 \mu \mathrm{g} / \mathrm{ml}$} & \multicolumn{2}{|c|}{$50 \mu \mathrm{g} / \mathrm{ml}$} \\
\hline & & Sample & Control* $^{*}$ & Sample & Control* $^{*}$ \\
\hline A & 4 & 4 & 1 & 4 & 0 \\
\hline B & 5 & 5 & 0 & 4 & 0 \\
\hline $\mathrm{O}$ & 4 & 4 & 1 & 3 & 0 \\
\hline $\mathrm{AB}$ & 4 & 3 & 1 & 3 & 0 \\
\hline Total & 17 & 16 & 3 & 14 & 0 \\
\hline
\end{tabular}

* Negative control samples treated with $0.05 \mathrm{M}$ orthoperiodic acid.

な発色が認められることを確認した.

つづいて，A， B, O および $\mathrm{AB}$ 型計 17 名分の有髄 毛髪を用いて, VECTOR のビオチン標識抗 Hレク チンの至適希釈濃度について検討を行った結果を Table 1 に示す．希瀵濃度 $100 \mu \mathrm{g} / \mathrm{ml}$ の場合, $\mathrm{AB}$ 型 の 1 試料を除いて，いずれの試料においても発色が 認められた。 また， $\mathrm{A}$ 型， $\mathrm{O}$ 型および $\mathrm{AB}$ 型それ ぞれ 1 試料において, 陰性対照毛髪の毛髄質に弱い 非特異的発色が認められた。希釈濃度 $50 \mu \mathrm{g} / \mathrm{ml}$ に おいては，いずれの試料に打いても，Fig. 1 に示す ように, 陰性対照試料に抢ける非特異的な発色は認 められなかったが, $100 \mu \mathrm{g} / \mathrm{ml}$ と比較して発色が弱 い傾向にあり， $\mathrm{B}$ 型，O 型および $\mathrm{AB}$ 型それぞれ 1 試料において, 発色が弱いために判定困難となっ た。 なた， $100 \mu \mathrm{g} / \mathrm{ml}$ および $50 \mu \mathrm{g} / \mathrm{ml}$ いずれの場合 も, 発色の強さは試料ごとに異なっていた.

なお，SIGMA およびWAKOにおいては，希釈 濃度を変えても非特異的反応を完全には抑えること ができなかった（Data not shown）.

\section{2 毛髪の酵素抗体法による $\mathbf{A B O}$ 式血液型検査の 改良}

\section{2-1 発色基質の検討}

$\mathrm{A}, \mathrm{B}, \mathrm{O}$ および $\mathrm{AB}$ 型の有髄および無髄毛髪を試 料とし, 発色基質の検討を行い, 実体顕微鏡にて落 射光下で観察した結果を Fig. 2 に示す。無髄毛髪 に抢いては，TMB を発色基質とした場合，過ヨウ 素酸処理した陰性対照毛髪とは明らかに異なる, 線 状の青い発色が毛皮質に認められた。AECを用い 


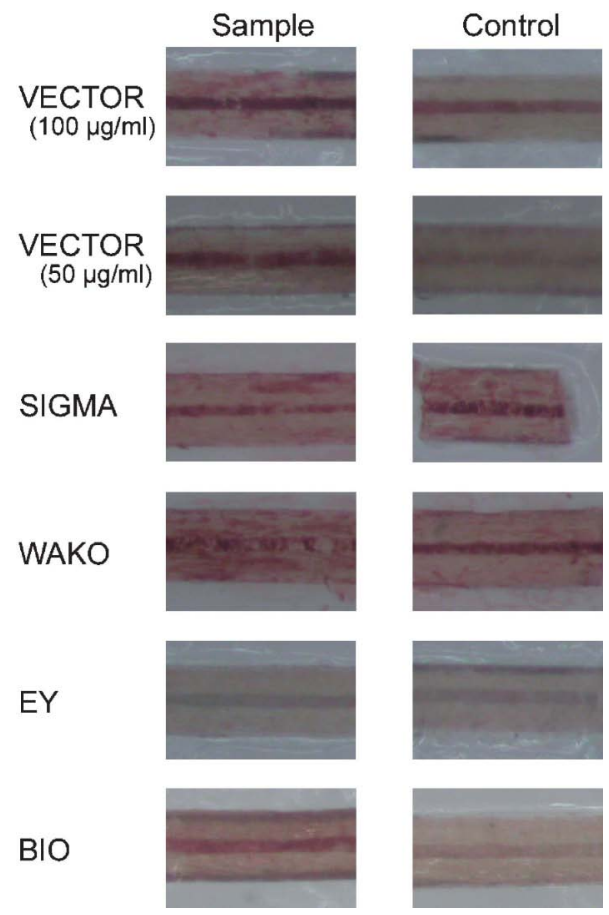

Fig. 1. Comparison of reactivities of four biotinconjugated ulex europaeus agglutinin 1 for immunohistochemical staining of scalp hair.

Dilution of $100 \mu \mathrm{g} / \mathrm{ml}$ of four manufacturers' biotin-conjugated ulex europaeus agglutinin 1 (biotin-UEA-1) and dilution of $50 \mu \mathrm{g} / \mathrm{ml} \mathrm{Vec-}$ tor Laboratories' biotin-UEA-1 were applied to longitudinally sectioned scalp hair. Following the reaction at $4^{\circ} \mathrm{C}$ overnight, the sample was treated with peroxidase-conjugated streptavidin and then stained with AEC as the substrate. Stained samples were observed with a conventional stereomicroscope. VECTOR: Vector Laboratories, WAKO: Wako pure chemical industries, EY: EY Laboratories, BIO: Biomeda. Control: Negative control samples treated with $0.05 \mathrm{M}$ orthoperiodic acid.

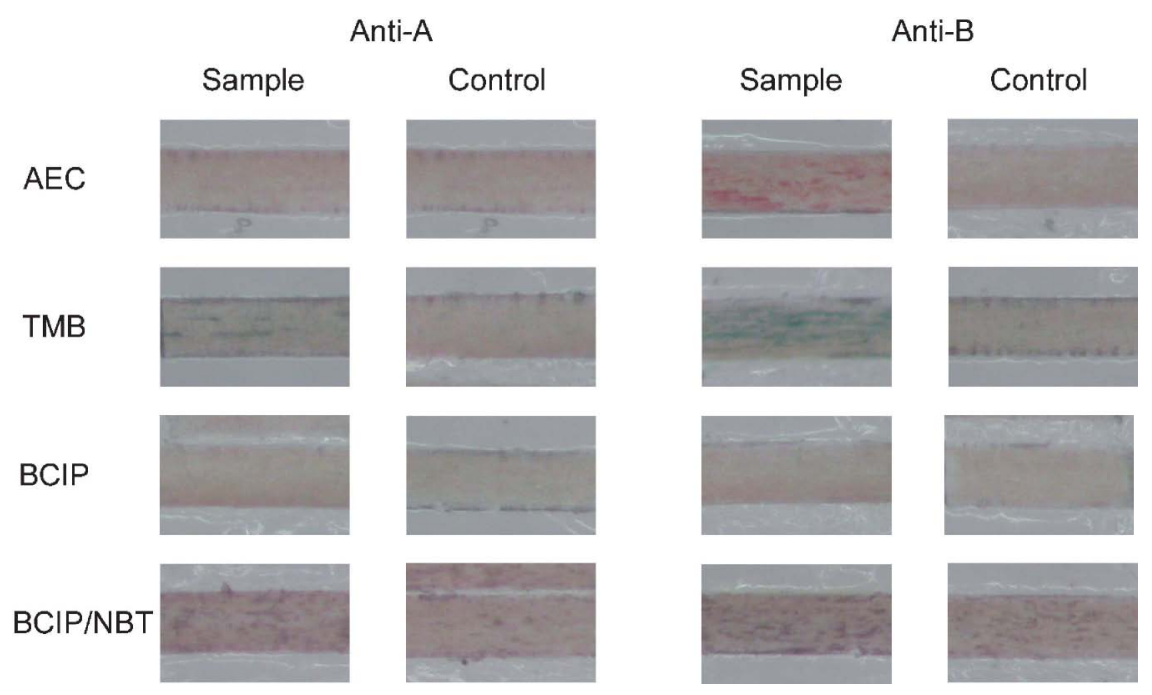

Fig. 2. Comparison of four chromogenic substrates in the ABO blood grouping of scalp hair by immunohistochemical staining.

Longitudinally sectioned scalp hair (type-AB) was incubated with mouse anti-A and anti-B monoclonal antibody. The sample was then treated with biotin-conjugated goat anti-mouse $\operatorname{IgG}+\operatorname{IgA}+\operatorname{IgM}$ followed by peroxidase-conjugated or alkaline phosphatase-conjugated streptavidin. The sample was then stained with AEC or TMB for substrates of peroxidase, or BCIP or BCIP/NBT for substrates of alkaline phosphatase, respectively, and observed with a conventional stereomicroscope.

AEC: 3-amino-9-ethyl-carbazol, TMB: 3,3',5,5'-tetramethylbenzidine, BCIP: 5-bromo-4-chloro-3indolylphosphate $p$-toluidine, NBT: nitroblue tetrazolium chloride. Control: negative control samples treated with $0.05 \mathrm{M}$ orthoperiodic acid. 
た場合でも発色は認められたが, 発色の程度は TMB と比較して弱く, 特に抗 A 抗体を反応させた 試料では, 毛髪中のメラニン色素との識別が困難な 場合があった。

有髄毛髪においては，AECを発色基質とした場 合, 既報7,8) と同様に, 毛髄質に特異的な赤色の発 色が認められ, 過ヨウ素酸処理した陰性対照毛髪に 抢ける非特異的発色は認められなかった。一方,

TMB では, 一部の有髄毛髪において, 毛髄質が非 特異的にやや青く発色していた（Data not shown).

BCIP を発色基質とした場合は，Fig. 2 に示すよ うに，いずれの毛髪に対しても特異的な青い発色は 認められなかった。一方, BCIP/NBT を発色基質 とした場合は, Fig. 2 に示すように, いずれの毛髪 に対しても毛皮質および毛髄質に強い非特異的発色 が認められたのに加え, 発色が濃紫色から黒色であ るため, 毛髮のメラニン色素との識別が困難であっ た。

\section{2-2 抗体の検討}

TMB による毛髄質の非特異的発色を改善するた め，オーソ，ワコー，イムコア拈よびコクサイの 4 種の抗 A 抗体抢よび抗 B 抗体を用いて, 一次抗体 の検討を行った. その結果, ワコー, イムコアおよ びコクサイの抗体を用いても, オーソの抗体と同様 の特異的発色は認められたものの，いずれの抗体を 用いても, 毛髄質における非特異的発色を改善する ことはできなかった（Data not shown）.

\section{2-3 ブロッキング条件の検討}

TMB による毛髄質の非特異的発色を改善するた め, ブロッキング条件の検討を行った．その結果，

TMB による毛髄質の非特異的発色は, ブロッキン グに 5\%のブロックエースあるいはスキムミルクを 用いることで減少したが，同時に特異的発色も弱ま る傾向にあった。 また, 同様の傾向は濃度を $2 \%$ に 下げても認められた，そこで，10\%ウサギ正常血清 を用いたブロッキングを $37^{\circ} \mathrm{C}$ で 1 時間行ったとこ ろ, 特異的発色を維持したまま非特異的発色を抑え ることが可能であった。な抏，BSAについては， 毛皮質および毛髄質全体にわたって強い青色の非特 異的発色を生じた（Data not shown）.

\section{2-4 検査法の検証}

改良した検査法で染色した有髄および無髄毛髪を 光学顕微鏡にて観察したところ, Fig. 3 に示すよう に，抗 A 抗体あるいは抗 B 抗体によって，毛皮質 が点状あるいは線状に発色していることが確認され た。一方，抗 Hレクチンでは，毛皮質全体にわた つて点状に発色していた。つづいて，有髄毛髪およ び無髄毛髪各17名分を用いて, 改良した検査法の検 証を行った、鑑定実務を想定し，実体顕微鏡にて落 射光下で観察した, 各血液型の有髄毛髪および無髄 毛髪に打ける発色例をFig. 4 に, 有髄毛髪打よび 無髄毛髪各17名分を用いた検証結果を Table 2 に示 す. 抗 Hレクチンによる発色が非常に弱い試料が 認められたものの，いずれの毛髮に打いても，あら かじめ判明している血液型と矛盾しない判定結果が 得られた. 発色の強度やバランスは試料ごとに異な っていたが，全体として，無髄毛髪の毛皮質におい て, 抗 B 抗体に比べて抗 A 抗体による発色が弱い 傾向㧍よび B 型毛髪の抗 H レクチンによる発色が 弱い傾向が認められた。

\section{2-5 ブラインドテスト}

確立した検査法について，ブラインドテストを実 施した結果, 有髄, 無髄を問わず, 各抗体に対して $1 \mathrm{~mm}$ 長に切断した試料を用いれば，48試料いずれ に対しても正しく血液型を判定することができた (Table 3).

Table 2 Verification of the modified protocol of immunohistochemical staining for ABO blood grouping of scalp hair.

\begin{tabular}{cccccc}
\hline \multirow{5}{*}{$\begin{array}{c}\text { Blood } \\
\text { group }\end{array}$} & $\begin{array}{c}\text { Number } \\
\text { of hair } \\
\text { donors }\end{array}$ & \multicolumn{2}{c}{$\begin{array}{c}\text { Number of positively } \\
\text { stained samples }\end{array}$} \\
\cline { 4 - 6 } Medullated & A & 4 & 4 & 0 & 4 \\
& B & 5 & 0 & 5 & 5 \\
& O & 4 & 0 & 0 & 4 \\
& AB & 4 & 4 & 4 & 4 \\
\hline \multirow{3}{*}{ Non- } & A & 4 & 4 & 0 & 3 \\
medullated & B & 4 & 0 & 4 & 3 \\
& O & 5 & 0 & 0 & 3 \\
& AB & 4 & 4 & 4 & 4 \\
\hline
\end{tabular}




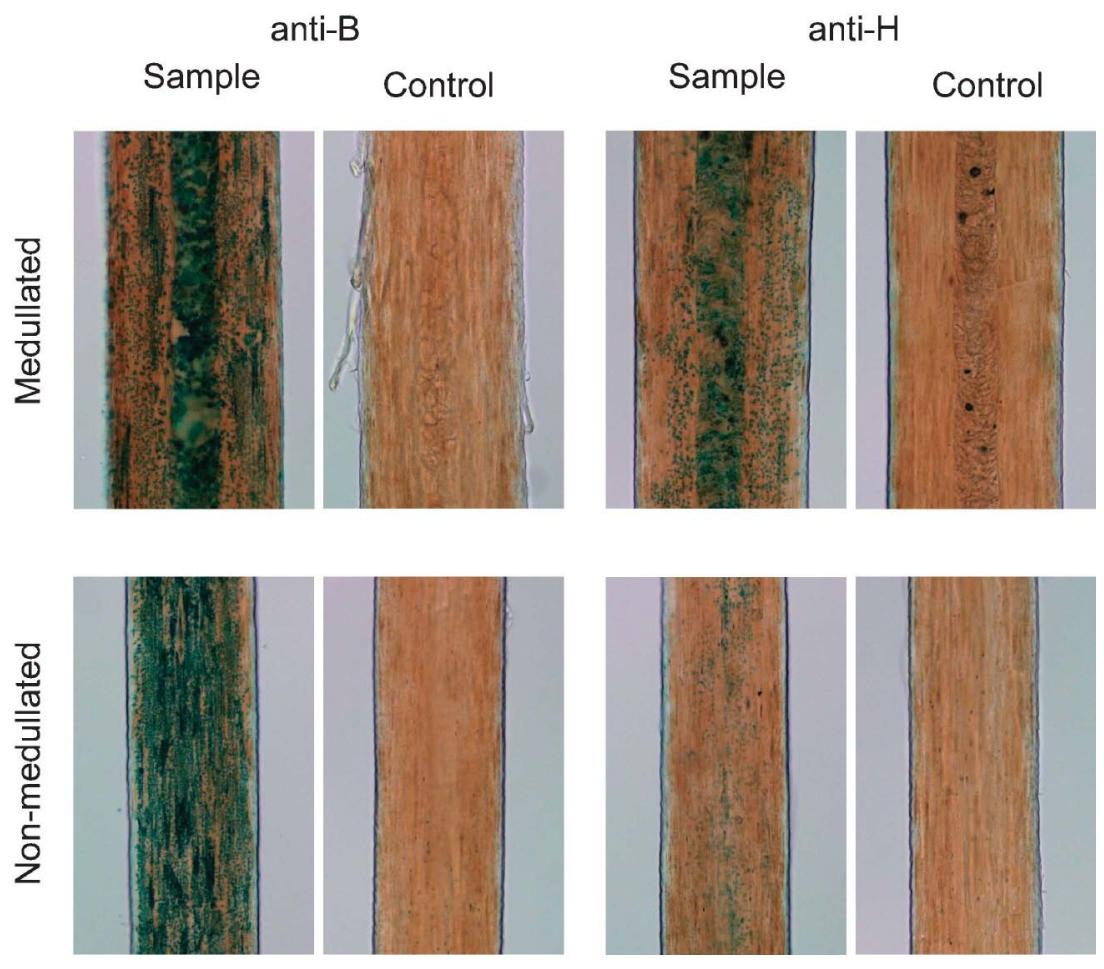

Fig. 3. Positive or negative staining of scalp hairs in the ABO blood grouping using modified immunohistochemical method.

Medullated and non-medullated scalp hairs (type-AB) were longitudinally sectioned and incubated with mouse anti-B monoclonal antibody or biotin-conjugated ulex europaeus agglutinin $\mathrm{I}$ at $4^{\circ} \mathrm{C}$ overnight. The samples were then treated with biotin-conjugated goat anti-mouse $\operatorname{IgG}+\operatorname{Ig} \mathrm{A}+\operatorname{IgM}$ (for anti-B antibody) followed by peroxidase-conjugated streptavidin. The samples were then stained with 3,3',5,5'-tetramethylbenzidine as the substrate and observed with a conventional light microscope. Control: negative control sample treated with $0.05 \mathrm{M}$ orthoperiodic acid before immunohistochemical staining.

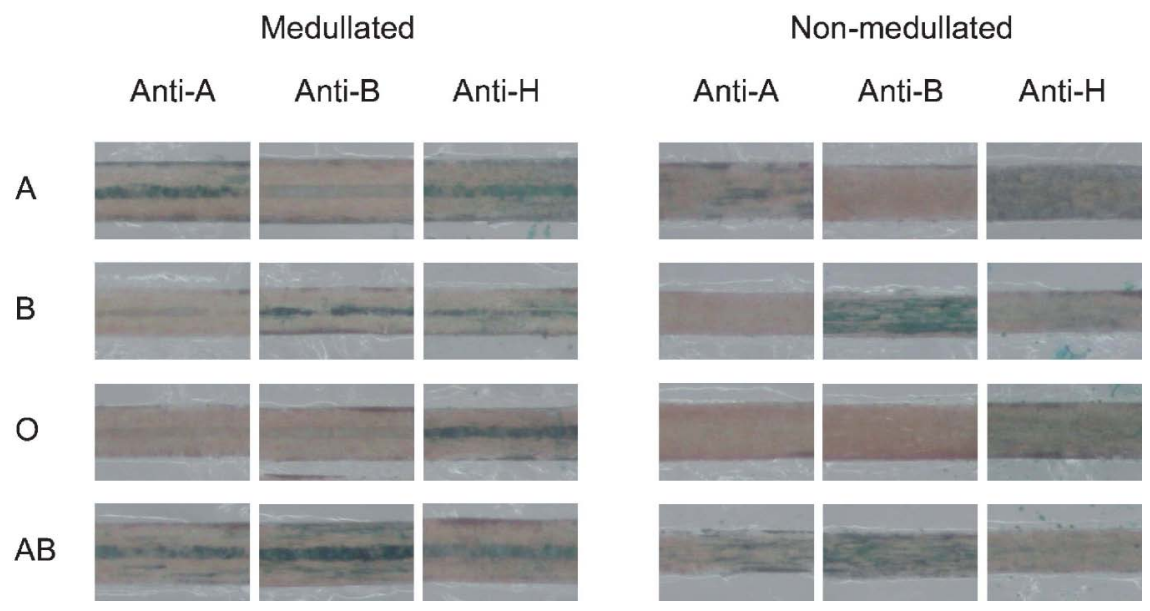

Fig. 4. Stereomicrographs of the immunohistochemical staining in medullated and non-medullated scalp hairs. $\mathrm{ABO}$ blood grouping of scalp hairs (type- $\mathrm{A}, \mathrm{B}, \mathrm{O}$ and $\mathrm{AB}$ ) was performed by modified immunohistochemical method. Assuming the actual forensic caseworks, the immunostainability of each hair sample was evaluated under a conventional stereomicroscope. 
Table 3 Results of the blind trial of ABO blood grouping of scalp hair using modified immunohistochemical staining.

\begin{tabular}{cccccc}
\hline & \multirow{2}{*}{$\begin{array}{c}\text { Blood } \\
\text { group }\end{array}$} & \multirow{2}{*}{$\begin{array}{c}\text { Number of } \\
\text { hair donors }\end{array}$} & Correct & Incorrect & Not determined \\
\cline { 4 - 6 } Medullated & $\mathrm{A}$ & 9 & 9 & 0 & 0 \\
& $\mathrm{~B}$ & 4 & 4 & 0 & 0 \\
& $\mathrm{O}$ & 5 & 5 & 0 & 0 \\
& $\mathrm{AB}$ & 5 & 5 & 0 & 0 \\
\hline \multirow{5}{*}{ Non-medullated } & $\mathrm{A}$ & 7 & 7 & 0 & 0 \\
& $\mathrm{~B}$ & 6 & 6 & 0 & 0 \\
& $\mathrm{O}$ & 7 & 7 & 0 & 0 \\
\hline & $\mathrm{AB}$ & 5 & 5 & 0 & 0 \\
\hline
\end{tabular}

\section{考 察}

鑑定実務における酵素抗体法（LSAB 法）による 毛髪の $\mathrm{ABO}$ 式血液型検査に用いられてきた, BIO のビオチン標識抗 Hレクチンが入手不可能となっ たことから，現在入手可能な VECTOR, SIGMA, WAKO およびEY のビオチン標識抗 H レクチンに ついて，鑑定実務に適用可能かどうか検討を行っ た.その結果, VECTORのビオチン標識抗 Hレク チンを $50 \mu \mathrm{g} / \mathrm{ml}$ に希釈して使用することで, 発色 はやや弱いものの, 非特異的発色を生じないことが 示された。したがって, 鑑定実務におけるLSAB 法による毛髪の ABO 式血液型検査には, VECTOR のビオチン標識抗 Hレクチンを, 非特異的発 色が認められない希釈濃度である $50 \mu \mathrm{g} / \mathrm{ml}$ で使用 するのがよいことが示された。

つづいて，鑑定資料の毛髄質の有無を問わず適用 可能な, 酵素抗体法による $\mathrm{ABO}$ 式血液型検査法を 確立するため, 現行法の発色基質やブロッキング条 件の改良について検討を行ったところ, 青色に発色 し，AECょりも高感度な ${ }^{13)} \mathrm{TMB}$ を用いることで 無髄毛髪の毛皮質が線状に発色することが示され た. 他の血液型の毛髪や, 過ヨウ素酸処理した陰性 対照毛髪ではこのような線状の発色は認められなか ったため,この発色は血液型物質に特異的であるこ とが示された。しかし，TMBを用いた場合，陰性 対照毛髪や他の血液型の有髄毛髪の毛髄質に弱い非
特異的発色が認められたため, 一次抗体やブロッキ ング条件を検討した結果，室温で10分間行っていた $10 \%$ ウサギ正常血清によるブロッキングを $37^{\circ} \mathrm{C} て ゙ ~ 1$ 時間とすることで，毛髄質における非特異的発色を 抑えることができた．改良した検査法で染色した有 髄および無髄毛髪を光学顕微鏡にて観察したとこ 万, 抗 A 抗体および抗 B 抗体では毛皮質が点状あ

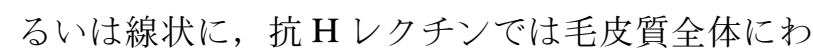
たって点状に発色していることが確認された。つづ いて，多試料による検証抢よびブラインドテストを 実施したところ, 発色の強さは試料ごとに異なって いたものの，各抗体に対して $1 \mathrm{~mm}$ 長の試料を用い ることで，各血液型の有髄および無髄毛髪いずれに おいても血液型を正しく判定することができた。し たがって，本法により，鑑定資料の毛髄質の有無を 問わず，酵素抗体法による毛髪の $\mathrm{ABO}$ 式血液型検 査が実施可能であることが示された。なお，顕微鏡 写真では光学顕微鏡像に劣るものの, 判定自体は実 体顕微鏡にて落射光下で十分可能であったことか ら，鑑定実務においては，より簡便な実体顕微鏡を 用いて判定を行えばよいと考えられた.

毛幹部，毛皮質に打ける血液型物質は，Intermacrofibrillar Matrix（ケラチン線維間基質）に局 在することが免疫電顕法により確認されており12), 本検討で確認された毛皮質の発色は，この部位に局 在する血液型物質を検出しているものと考えられ る. 発色基質として現行法の AECを用いた場合で 
も，毛皮質に線状の発色が認められたが，AECに よる発色はメラニン色素と混同しやすい赤色であ り, かつ TMB と比較して感度が低いことから, 陰 性対照との比較なしに判定することが困難な試料も 見受けられ，これまでの報告においても判定できて いなかったのではないかと考えられた。 また，毛髪 を試料として血液型検査を実施する場合，圧挫など により抗原を十分に露出させる必要があり ${ }^{14,15)}$, 高 圧で均一に圧挫した試料では，皮質全体に発色が認 められるとの報告11)があるが，今回のように，メス を用いて縦断切片を作成する方法でも，縱断切片の 切断面は粗面々なることから，多くの抗原が露出 し，発色しやすくなったものと考えられた。なお， 本研究では, $\mathrm{A}$ 型および $\mathrm{B}$ 型物質と, $\mathrm{H}$ 型物質と で異なる発色パターンが認められた。その原因は明 らかではないが，検討に使用した抗 $\mathrm{A}$ 抢よび抗 $\mathrm{B}$ 抗体が 5 量体の IgM であるのに対し, 抗 Hレクチ ン (ulex europaeus agglutinin I) は分子量約 6 万か ら6.8万の 2 量体16)であり，血液型抗原に対する反 応性が異なることが原因となる可能性が考えられ る.

今回， $\mathrm{A}, \mathrm{B}$ 抢よび $\mathrm{AB}$ 型の無髄毛髪の毛皮質に 共通して, 抗 B 抗体と比較して抗 A 抗体に対する 発色が弱い傾向が認められた。毛髪においては, 抗 B 抗体と比較して, 抗 A 抗体に対する反応性が低 いことは以前から知られており，伊藤ら ${ }^{17)}$ は， $\mathrm{AB}$ 型の個人由来の頭毛および爪について解離試験法に よる血液型判定を実施したところ，爪については全 例で $\mathrm{AB}$ 型と正しく判定できたが，一部の頭毛につ いては抗 A 血清に対する判定が陰性となり，B型 と誤判定されることを報告している。 また，モノク ローナル抗体を用いた毛髮の解離試験法において も，抗 A 抗体に対する反応性の低さを補うため, 抗 A 抗体を感作させる試料量を抗 B 抗体の 2 倍に して実施している3 . 毛髪中の A 型物質は, 毛髪中 に発現する $\alpha-N$-acetylgalactosaminidase により $\mathrm{H}$ 型物質へと分解され，その量が減少することが報告 されており18)，このことが抗 $\mathrm{A}$ 抗体に対する反応 性の低さおよび抗 Hレクチンに体する A 型毛髪と $\mathrm{B}$ 型毛髪の反応性の違いの原因と考えられる． AB 型の無髄毛髪においては, 抗 A 抗体と抗 B 抗体に
よる発色の程度が異なることを念頭に置き, 対照資 料と比較しながら判定を行う必要があると考えられ た。

また今回, 試料間で各抗体に対する発色の強さが 異なっていたが，発色の強弱と体液の分泌・非分泌 型とは関連していなかった。毛髪中の ABO 式血液 型物質は, 糖タンパク質ではなく糖脂質であると推 定されており19-21)，毛髮の解離試験においても，血 球凝集の強弱と体液の分泌 · 非分泌型との間には関 連性はないことが報告されていることから 22), 本検 討に拈いても矛盾のない結果が得られた.

\section{結 語}

酵素抗体法におけるブロッキング条件や発色基質 を改良することで, 資料の毛髄質の有無を問わず $\mathrm{ABO}$ 式血液型を判定することができ, 短い無髄毛 髪からも ABO 式血液型検査が実施可能となった. 本法は, DNA 型鑑定の前段階での資料の選別法と して有用である.

\section{文 献}

1) Yada, S., Okane, M. and Sano, Y.: Blood grouping of a single human hair by means of elution technique. Act. Crim. Japon., 32, 7-8 (1966).

2) Ohmori, T. and Sato, H.: The optimum elution temperature and time in absorption-elution test using commercially available monoclonal antibodies for ABO blood-typing from hair samples. Jpn. J. Sci. Tech. Iden., 6, 49-55 (2001).

3) 大森毅, 荒木直幸, 城野博文, 五十嵐史 子, 廣重憲一, 土屋昌弘, 佐藤 元 : 市販乇ノ クローナル抗体を用いた毛髪からの解離試験に よる $\mathrm{ABO}$ 式血液型判定. 法医学の実際々研 究, 44, 85-88 (2001).

4) 宮坂祥夫, 吉野峰生, 佐藤 元, 向山明孝, 瀬田季茂: 微量毛髪の血液型判定に関する免疫 組織化学的検討. 科警研報告, 37, 27-35 (1984).

5) Miyasaka, S., Yoshino, M., Sato, H., Miyake, B. and Seta, S.: The ABO blood grouping of a 
minute hair sample by the immunohistochemical technique. Forensic Sci. Int., 34, 85-98 (1987).

6) Pötsch-Schneider, L., Penzes, L. and Lorenz, K.: immunenzymatische ABO-blutgruppenbestimmung am Einzelhaar I. Z Rechtsmed., 97, 251258 (1986).

7）内村裕光, 宮北省二, 浜田希世, 岩瀬晋, 本 庄弘次, 恒成茂行：Labelled Streptavidin Biotin 法による毛髪の $\mathrm{ABO}$ 式血液型判定. 科警研報 告, 49, 9-15 (1996).

8) 内村裕光, 宮北省二：鑑定実務における Labelled Streptavidin Biotin 法による毛髪の $\mathrm{ABO}$ 式血液型検査. 科警研報告, $53,26-28$ (2000).

9) Nishi, K., Annuss, B., Rand, S. and Brinkmann, B.: ABO blood grouping of hairs using an avidin-biotin-peroxidase complex technique. Z. Rechtsmed., 102, 247-254 (1989).

10）橋本良明, 高橋直子, 守屋文夫, 中西祥徳 : ビオチン標識タイラマイドによるシグナル増幅 法を用いた毛髪からの ABO 式血液型検出. 法 医学の実際と研究，44，171-175 (2001).

11）松井清司, 西尾 元, 鈴木廣一: 圧挫試料を 用いた酵素抗体法による毛髪の $\mathrm{ABO}$ 式血液型 検査. 日法医誌, 62, 113-117 (2008).

12) Miyasaka, S., Yoshino, M., Sato, H., Miyake, B. and Seta, S.: Light and electron immunohistochemical demonstration of $\mathrm{ABH}$ blood group substances in Mongolian and Caucasian head hairs. Can. Soc. Forensic Sci. J., 20, 246247 (1987).

13 Hosoda, H., Takasaki, W., Oe, T., Tsukamoto, R. and Nambara, T.: A comparison of chromogenic substrates for horseradish peroxi- dase as a label in steroid enzyme immunoassay. Chem. Pharm. Bull., 34, 4177-4182 (1986).

14）北浜睦夫, 池本卯典, 金羽レイ, 向山明孝, 荍内善悟, 平野幸五郎, 渡辺満子, 宮本尚之, 大西永一, 余島弘造, 福山 武: 毛髪からの解 離試験による血液型判定法について、科警研報 告, 21, 106-115 (1968).

15）向山明孝, 瀬田季茂 : 毛髪の血液型と犯罪鑑 識への応用. 捜査研究, 32, 48-63 (1983).

16) Van Damme, E. J. M., Peumans, W. J., Pusztai, A. and Bardocz, S.: Handbook of plant lectins: properties and biomedical applications. pp. 397-399, John Wiley \& Sons, England (1998).

17）伊藤喜美子, 羽場喬一：AB 型の毛髪と爪の 血液型判定. 日法医誌，34，694-696 (1980).

18) Kimura, A., Kanekura, T., Saito, Y., Sagawa, K., Nosaka, M., Kanzaki, T. and Tsuji, T.: Blood group A glycosphingolipid accumulation in the hair of patients with alpha-N-acetylgalactosaminidase deficiency. Life Sci., 76, 1817-1824 (2005).

19）酒井哲哉：人毛髪の血液型物質に関する研 究. 日法医誌，5，19-41 (1951).

20）岸紘一郎：ヒト毛髪から得られた $\mathrm{A}$ 型物質の 免疫化学的性状について. 科警研報告, 30, 1-4 (1977).

21）岸紘一郎：ヒト毛髪から得られた $\mathrm{H}$ および $\mathrm{B}$ 型活性のある糖脂質の免疫化学的性状. 科警研 報告，31, 9-11 (1978).

22）矢田昭一, 岡根光代, 佐野靖子 : 解離試験に よる諸種体毛からの血液型判定. 犯罪学雑誌, 32, 52-55 (1966). 